\title{
The impossibility of linear reading the evolution of reinforced concrete: the case of Spain (1896-1973)
}

\author{
M. Sagarna, L. Etxepare Igiñiz, I. Lizundia \& E. Uranga \\ EHU/UPV, Donostia-San Sebastian, Spain
}

\begin{abstract}
The evolution of the quality of an artificial material in subsequent periods should not present setbacks. Technological development and monitoring the execution should ensure a favourable outcome in quality. However, socioeconomic and political forces can distort the course of this evolution, making it impossible for a linear reading; serving as an example of this is the history of reinforced concrete in Spain. The material was introduced to Spain about 120 years ago from European patents. After the war, and after several glorious decades, came the decline of these patents with the consequent liberalization of the technology and the publication in 1939 of Instruction for Concrete. This liberalization came into effect in a context of scarcity and high cost of construction materials, so that the concrete used in the reconstruction of the cities turned out to be a very poor material. Various decrees and orders published at this time established a number of limitations in the use of iron and cement, both depleting the quality of the material used, and as a result, developing a black market, further adding to the decline in quality. Later in the $60 \mathrm{~s}$, overcoming these constraints, the quality of materials began to improve. In 1973, a new regulation on the use of concrete introduced a section on quality control. Thereafter, the increasing control ensured the proven quality of the material and its continuous improvement to the present day. A series of tests conducted in buildings made of reinforced concrete in the Basque Country during the twentieth century, shows that the strength and quality of concrete from 100 years ago can be much better than of concrete from 60 years ago, attesting to the inability to perform a linear reading of its evolution. Keywords: concrete, history, quality, patents, regulations, restrictions.
\end{abstract}




\section{Introduction}

The evolution of the quality of an artificial material adopted in successive periods should not present setbacks. Technological development and the monitoring of implementation should ensure a steady improvement in standards.

However, socioeconomic and political events can distort the course of this evolution, making a linear reading impossible; serving as an example of this is the history of reinforced concrete in Spain.

\section{The introduction of reinforced concrete in Spain (1893-1939)}

The use of a material which is particles of stone collected or secured by a binding agent dates back to previous civilizations.

However, the standard of what we today know as concrete came from the industrial production of artificial cement known as Portland cement.

It was Joseph Aspdin who patented this process in Spain in 1824 but industrial production did not exist until the late nineteenth century: Tudela Veguin in Asturias (1898), Cementos Rezola in Gipuzkoa (1900), General Company of Asphalt and Portland Asland, SA in Catalonia (1901), would be the first ones to produce it.
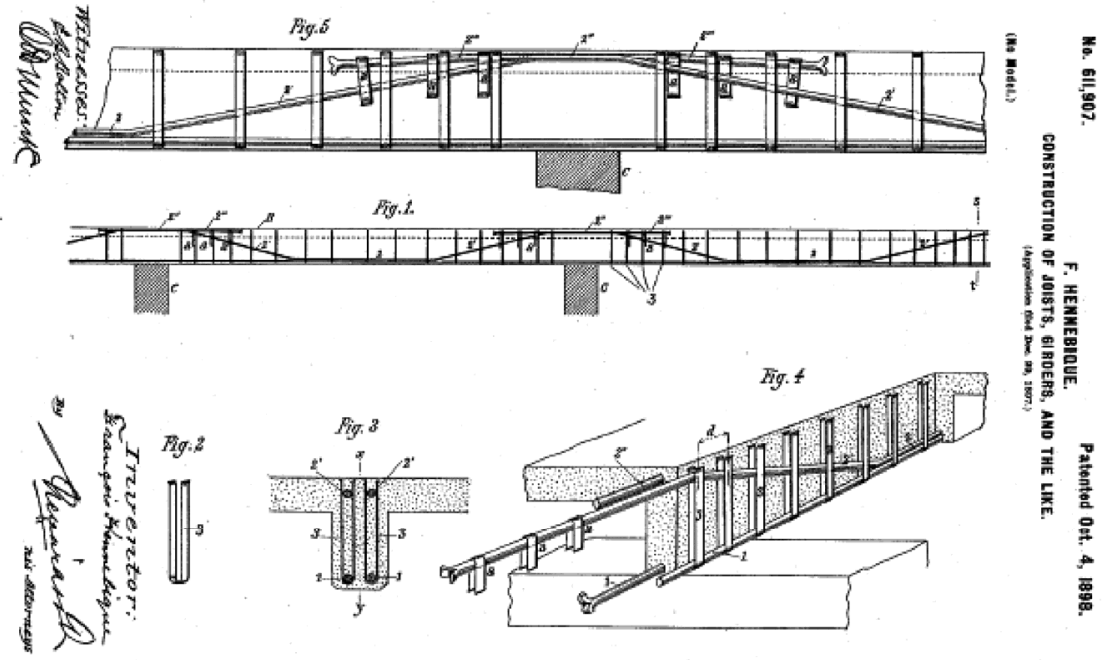

Figure 1: Hennebique patent.

It was during this period that the combination of conglomerate and iron began, thus providing resistance to tensile stresses in all types of construction.

The use of this material spread worldwide through "secret" patents. The two most important patents (Monier and Hennebique) arrived in Spain through 
Francesc Macia in 1893 (Patent Dealer Monier) and José Antonio Ribera in 1898 (Patent Dealer Hennebique).

But still it was not known how this material really functioned, being rather intuitive and experimental work. Therefore, the first works that were done with the new material did not use rules or regulations to guide their calculation, design or execution.

There was a blind confidence in the new material, greatly valued for its incombustibility (significant advantage over steel structures that were widely used until now), waterproofing, economics and health. The application of the material during the first decade of the twentieth century in Spain focused mainly on public works, equipment and factories. The use of the material under these "recipes" ran during the first third of the twentieth century.

As for quality control, at this time, the quality of concrete was measured by visual appreciation and experience with its use. There was almost no test equipment for the concrete itself.

In 1936, due the Civil War, the construction industry suffered a paralysis: the construction of many buildings was halted between 1936 and 1938 .

The postwar economic system, born on the basis of a growing economic interventionism in previous decades, with the sole purpose of rearming (to support totalitarian countries, Italy and Germany) over any other considerations, such as urban reconstruction.

José María de Areilza, who occupied a high position in the Franco administration made the following speech [1] in 1940:

"In developing a political autarchy (...) lies the key to the economic future of Spain. There is in fact no other authentic national reconstruction plan, but this: the looking out. And it would be an unfortunate mistake to suppose that the great postwar reconstructive project is limited to the rebuilding of a few urban centers destroyed by shrapnel, or restoration of public works smashed by dynamite. This is necessary and indispensable (...) but in the end, what matters above all is our autarchy, that's to say, a total external freedom of Spain against the world."

Several buildings constructed with reinforced concrete have been studied from this time [2]. The compressive strength tests carried out show the following results (see table 1 ).

\section{The postwar period (1939-1960)}

With the end of the war came the decline of the patents. Treatises and instructions on the use of reinforced concrete appeared throughout Europe.

Several engineers developed scientifically based theories, and began to abandon the 'secret' patents for those based on scientific treatises on construction employing reinforced concrete. The need for regulation is evident as the calculations that had already begun to be developed had to abide by laws. As these treatises and regulations were published, the old style patents disappeared. 
44 Structural Studies, Repairs and Maintenance of Heritage Architecture XIV

Table 1: Average and characteristic compressive strengths in buildings constructed between 1901 and 1934.

\begin{tabular}{|c|c|c|c|}
\hline $\begin{array}{c}\text { Construction } \\
\text { year }\end{array}$ & $\begin{array}{c}\text { Characteristic } \\
\text { strength } \\
\mathrm{N} / \mathrm{mm}^{2} \\
\end{array}$ & $\begin{array}{l}\text { Average } \\
\text { strength } \\
\mathrm{N} / \mathrm{mm}^{2} \\
\end{array}$ & Building \\
\hline 1901 & 16.56 & 12.25 & $\begin{array}{l}\text { La Ceres } \\
\text { (Bilbao) }\end{array}$ \\
\hline 1903 & 15.09 & 9.31 & $\begin{array}{l}\text { Zarautz Market } \\
\text { (Zarautz) }\end{array}$ \\
\hline 1909 & 17.44 & 12.05 & $\begin{array}{c}\text { Alhondiga Bilbao } \\
\text { (Bilbao) }\end{array}$ \\
\hline 1910 & 23.91 & 25.48 & $\begin{array}{l}\text { Queen Victoria nursing } \\
\text { home } \\
\text { (Donostia) }\end{array}$ \\
\hline 1916 & 18.33 & 9.41 & $\begin{array}{l}\text { Courthouse } \\
\text { (Donostia) }\end{array}$ \\
\hline 1918 & 26.56 & 20.29 & $\begin{array}{c}\text { Zankoeta desinfection } \\
\text { building } \\
\text { (Bilbao) }\end{array}$ \\
\hline 1919 & 22.54 & 9.51 & $\begin{array}{c}\text { Punta Begoña balcony } \\
\text { (Getxo) }\end{array}$ \\
\hline 1922 & 22.83 & 18.62 & $\begin{array}{c}\text { Villa Ducourau } \\
\text { (Irun) }\end{array}$ \\
\hline 1924 & 24.40 & 23.03 & $\begin{array}{l}\text { Residential building } \\
\text { (Santurtzi) }\end{array}$ \\
\hline 1929 & 27.44 & 17.25 & $\begin{array}{l}\text { Ribera Market } \\
\text { (Bilbao) }\end{array}$ \\
\hline 1934 & 30.58 & 14.80 & $\begin{array}{l}\text { Residential building } \\
\text { (Bilbao) }\end{array}$ \\
\hline
\end{tabular}

Reinforced concrete had passed from being a product to being a technique available to engineers, architects and builders.

The early twentieth century saw both France (1906) and Germany (1904) publish regulations on reinforced concrete, but not until 1939 did the first instruction in Spain appear, regulating the use of the new material.

At the same time, the delicate situation facing the country after the war, led the State to adopt strict regulatory measures that directly affected the construction industry. In this context it launched the National Reconstruction Plan, limiting consumption of certain materials and prioritizing use in other industries considered of greater national interest. In 1941 the first decree for limiting the use of iron [3] was issued, along with the relevant regulation, detailing the conditions to consider in building use.

In 1943 two Orders concerning the use of iron in construction [4] and the preference of supply of cement are added, in order to guarantee minimum amounts and maximum material savings. This caused the appearance of a black market for a quota increase of materials at a more expensive price. 
All these regulations and orders caused a reduction in the quality of construction, directly affecting durability. Besides the conditions of the industry at that time did not allow rigorous quality control in the production processes of various materials, and calculations were extremely tight. This caused the buildings constructed during the 20 year life of these measures to suffer very low build quality and very rapid aging.

As evidence of the unfortunate consequences that the economic reality had at this time on the quality of industrial production for the construction industry, Jaime Nadal, director of the Technical Institute of Construction and Cement recalled the following in 1959 [5]:

“(..) What until then was evolution, was converted into a competition; a competition of prices, opportunities, the money circulation rate, the accumulation of materials. In short, a competition run without a focus on quality, as speed was such that quality was more expensive, leaving whoever tried to secure it in danger of succumbing to the competition of those selling the same, but cheaper, though being evidently worse." "The average quality declined in all or almost all, while in Europe it rose slowly, but still rose. (...) The reality is that differences were accentuated."

The ultimate goal of the state was to avoid the use of steel for building and encourage the use of reinforced concrete, but it was a concrete pushed to its limits, with very low quality in both manufacture and application. (With the implementation of the decree of March 11 1941, it was legally impossible, in almost all cases, for buildings with steel structures: the limits of seven and ten kilograms of iron per cubic meter of building projects, official and private respectively, were enough to substitute them for reinforced concrete structures.)

Spanish technicians claimed since 1947 the improvement of the quality of articles elaborated within the industry. On Sept 26 1952, the decree finally appeared in which industry standards of quality are fixed.

Cement production increased significantly in the late forties, as would steel in the mid-fifties.

But still was valid the decree limiting the use of steel in construction [6], which, coupled with a more fluid cement supply, encouraged the development of reinforced concrete structures of small to medium span.

The black market for building materials was losing strength as the supply of basic materials expanded and the powers of intervention agencies were diminished.

Several buildings constructed with reinforced concrete at this time have been studied. (These tests have been consulted in GIKESA testing laboratory.) The compressive strength tests carried out show the following results (see table 2).

\section{Overcoming constraints (1960-1973)}

Later in the 1960s, overcoming the restrictions, the quality of materials begins to improve. In 1961 the Eduardo Torroja Institute of Construction and Cement published Instruction HA 61 for reinforced concrete structures, where a 
Table 2: Average and characteristic compressive strength in buildings built between 1940 and 1960 .

\begin{tabular}{|c|c|c|c|}
\hline Construction year & $\begin{array}{c}\text { Characteristic } \\
\text { strength } \mathrm{N} / \mathrm{mm}^{2}\end{array}$ & $\begin{array}{c}\text { Average } \\
\text { strength } \mathrm{N} / \mathrm{mm}^{2}\end{array}$ & Building \\
\hline 1946 & 19.15 & 20.11 & $\begin{array}{c}\text { Residential building } \\
\text { (Donostia) }\end{array}$ \\
\hline 1950 & 10.88 & 16.48 & $\begin{array}{c}\text { Civil Guard } \\
\text { headquarters } \\
\text { (Aretxabaleta) }\end{array}$ \\
\hline 1951 & 14.49 & 19.48 & $\begin{array}{c}\text { Berazubi stadium } \\
\text { (Tolosa) }\end{array}$ \\
\hline 1955 & 7.30 & 7.30 & $\begin{array}{c}\text { Residential building } \\
\text { (Trintxerpe) }\end{array}$ \\
\hline 1958 & 11.24 & 21.01 & $\begin{array}{c}\text { Vista Alegre tower } \\
\text { (Zarautz) }\end{array}$ \\
\hline
\end{tabular}

minimum characteristic resistance of $130 \mathrm{kp} / \mathrm{cm}^{2}\left(12.74 \mathrm{~N} / \mathrm{mm}^{2}\right)$ is established. However, although it was a policy that was followed by the industry at that time, the text had no official legal standing.

From this time on, several different decrees and orders aimed at regulating the quality of both materials and construction processes [9] were to appear:

- 1964: Hydraulic binders; measures to promote standardization and quality in production. Order of the Ministry of Industry of 06.24.1964 (In 1966 the Instruction for the implementation of the order would appear.)

- 1968: Instruction for the design and execution of works plain concrete or reinforced. Appeared as instruction on probation for a period of two years but actually extended until 1973 .

This last regulation set the lower limit of characteristic compressive strength of $120 \mathrm{kp} / \mathrm{cm}^{2}$ and determined a characteristic compressive strength for concrete more usual $180 \mathrm{kp} / \mathrm{cm}^{2}\left(17.64 \mathrm{~N} 7 \mathrm{~mm}^{2}\right)$.

The buildings that have been tested compressive strength analyzed gave the following results (see table 3). (These tests have been consulted in GIKESA testing laboratory.)

\section{Quality control regulation (EH-73)}

In 1973, the instruction for the design and execution of works in plain concrete or reinforced stated in its articles, as mandatory, the quality control of concrete, its component materials, the steel and the execution of the work [8].

The lower limit for its characteristic compressive strength will be $175 \mathrm{kp} / \mathrm{cm}^{2}$ $\left(17.15 \mathrm{~N} / \mathrm{mm}^{2}\right)$ recommending a level of $250 \mathrm{kp} / \mathrm{cm}^{2}\left(24.5 \mathrm{~N} / \mathrm{mm}^{2}\right)$ for a concrete building structures resistance.

Thereafter, the increasing control ensured a proven material quality and a continuous improvement to this day. 
Table 3: Average and characteristic compressive strength in buildings built between 1960 and 1967 .

\begin{tabular}{|c|c|c|c|}
\hline $\begin{array}{c}\text { Construction } \\
\text { year }\end{array}$ & $\begin{array}{c}\text { Characteristic } \\
\text { strength N/mm² }\end{array}$ & $\begin{array}{c}\text { Average } \\
\text { strength } \\
\mathrm{N} / \mathrm{mm}^{2}\end{array}$ & Building \\
\hline 1961 & 13.00 & 14.54 & $\begin{array}{c}\text { Residential building } \\
\text { (Arrasate) }\end{array}$ \\
\hline 1962 & 14.10 & 15.66 & $\begin{array}{c}\text { Jakintza School } \\
\text { (Donostia) }\end{array}$ \\
\hline 1963 & 14.21 & 17.00 & $\begin{array}{c}\text { Residential building } \\
\text { (Elgoibar) }\end{array}$ \\
\hline 1965 & 15.52 & 19.25 & $\begin{array}{c}\text { Residential building } \\
\text { (Donostia) }\end{array}$ \\
\hline 1967 & 14.85 & 20.27 & $\begin{array}{c}\text { Residential building } \\
\text { (Donostia) }\end{array}$ \\
\hline 1967 & 15.55 & 18.65 & $\begin{array}{c}\text { Basanoaga Tower } \\
\text { (Errenteria) }\end{array}$ \\
\hline
\end{tabular}

Table 4: Average and characteristic compressive strength in buildings built between 1973 and 1978 .

\begin{tabular}{|c|c|c|c|}
\hline $\begin{array}{c}\text { Construction } \\
\text { year }\end{array}$ & $\begin{array}{c}\text { Characteristic } \\
\text { strength N/mm² }\end{array}$ & $\begin{array}{c}\text { Average } \\
\text { strength } \\
\mathrm{N} / \mathrm{mm}^{2}\end{array}$ & Building \\
\hline 1973 & 25.00 & 26.15 & $\begin{array}{c}\text { Residential building } \\
\text { (Getaria) }\end{array}$ \\
\hline 1976 & 25.65 & 27.22 & $\begin{array}{c}\text { Astigarraga School } \\
\text { (Astigarraga) }\end{array}$ \\
\hline 1978 & 25.84 & 26.73 & $\begin{array}{c}\text { Residential building } \\
\text { (Tolosa) }\end{array}$ \\
\hline
\end{tabular}

\section{Conclusions}

The results of tests conducted on various reinforced concrete structures corresponding to buildings made in the Basque Country throughout the twentieth century, show that concrete employed around the 1950s contains obvious deficiencies (as shown in figure 2).

A development in concrete quality has been variable depending on the time. The first reinforced concrete (1901-1939) has a tendency to increase its characteristic compressive strength, but the variation of one concrete to another is very important at this time.

The era of restrictions (1939-1960) saw concrete progressively diminish in quality and the values of compressive strength characteristics give very variable results. 


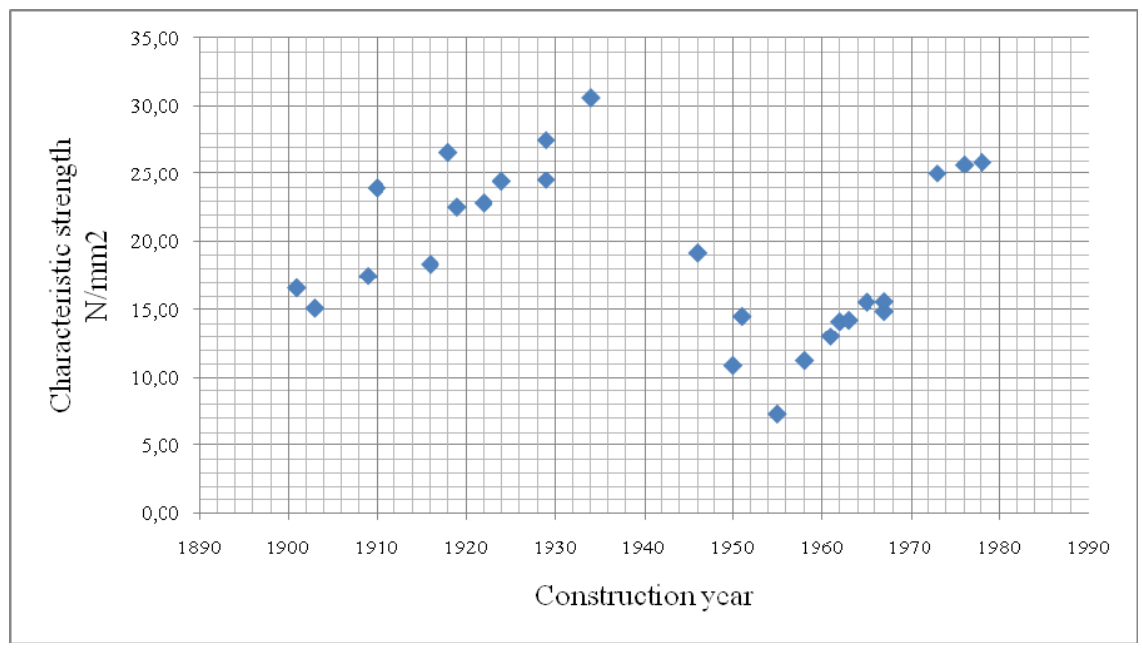

Figure 2: Characteristic resistance of witnesses analyzed.

Once a restriction era is finished and until the entry into force of the EH-73, although the trend of the compressive strength is generally increased, widely scattered values can still be seen.

However, when the quality control of the material was increased, the quality of concrete shows very similar stabilized resistance.

Since the entry into force of Regulation EH-73, an overall stabilization of the compressive strength test can be fully appreciated.

Therefore, these results demonstrate the impossibility of a linear reading of the evolution of the material, resulting in the following paradox: the resistance of concrete employed 100 years ago, and the condition in which it is found, are far in advance of that used four decades later.

\section{References}

[1] Areilza, José María de "Guidelines of the New Economic Order," Technical problems of economic importance in the new organization of Spain, University of Barcelona, Barcelona, 1940.

[2] Marcos, Iñaki, "Constructional features of pre-normative structures of reinforced concrete. Learning and study methodology aimed at rehabilitation. Unpublished doctoral dissertation, Bilbao, 2014.

[3] Boe. March 12, 1941 Regulation on restrictions on the use of iron in construction. Num. 71. pp. 1766-1767.

[4] Order of 8 July 1943 on the use of ferrous materials in the construction of buildings.

[5] Nadal, J. 1959. "Services Institute in conjunction with the technical construction at present," In Construction Reports, Vol. 116. 
[6] Decree 19/01/1956 removing restrictions of steel established by the decree of $03 / 11 / 1941$.

[7] Gomez Hermoso, J. 1997. Technical and economic analysis of the influence that presents the use of different materials and structural types in the project of building structures. Doctoral thesis. Polytechnic University of Madrid.

[8] Instruction for the design and execution of works involving plain mass or reinforced concrete 1968. $3^{\circ}$ Title. Chapter IX. Article 57. Quality Control. 